\title{
Pelatihan Bahasa Inggris Untuk Guru Paud Al-Hikmah Di Kelurahan Mayang Mangurai Kota Jambi
}

\author{
Nely Arif, Ernanda, Reny Heryanti, Duty Volya \\ FKIP, Universitas Jambi, Indonesia
}

\begin{abstract}
ABSTRAK
Belajar bahasa asing sangat baik jika dimulai sedini mungkin karena anak kecil sangat pandai meniru bunyi-bunyi yang baru dan beradaptasi dengan cara pengucapan bahasa. Otak mereka masih terbuka untuk mempelajari bunyi-bunyi dan pola bahasa baru. Pengajaran bahasa inggris pada sekolah PAUD selayaknya mendapat perhatian segala pihak terutama menyangkut tersedianya pengajar Bahasa Inggris yang berkompeten. Pengajar PAUD pada umumnya bukanlah lulusan Program Studi Pendidikan Bahasa Inggris yang benar-benar menguasai cara mengajar Bahasa Inggris. Mereka tidak dibekali strategi dan teknik mengajar Bahasa Inggris dan mereka harus belajar sendiri untuk kemudian mengajarkannya kepada anak. Kegiatan Pengabdian Kepada masyarakat ini telah dilaksanakan pada hari Selasa, tanggal 29 Juli 2020. Mengingat dan menimbang situasi belum kondusif dikarenakan masalah Covid-19, maka kegiatan ini dilakukan secara daring atau online dengan memanfaatkan aplikasi Zoom. Dari 12 guru yang deirencanakan ikut terlibat dalam online meeting ini, yang bisa hadir 9 orang karena yang lain terkendala dengan perangkat yang tidak bisa menginstal aplikasi Zoom. Kegiatan berjalan dengan lancar walaupun pada awalnya mengalami masalah yang kemungkinan disebabkan oleh perangkat komputer atau jaringan internet yang kurang stabil. Ini bisa menjadi pengalaman berharga baik kami sebagai pelaksana kegiatan PPM dan guru atau pihak sekolah mitra agar kedepannya bisa lebih baik lagi jika akan melaksanakan kegiatan serupa yang memanfaatkan online meeting via Zoom seperti ini.
\end{abstract}

Kata Kunci: PPM, Bahasa Inggris, PAUD

\section{PENDAHULUAN}

Sebelum memasuki jenjang pendidikan dasar, anak-anak sampai usia enam tahun dibekali pembinaan yang diharapkan dapat mempersiapkan jasmani dan rohani anak untuk melanjutkan pendidikannya. Pendidikan Anak Usia Dini (PAUD) merupakan program Kementerian Pendidikan dan Kebudayaan dan sekaligus merupakan komitmen dunia untuk menyediakan pendidikan yang berkualitas sejak lahir.

Dalam skala nasional, Pendidikan Anak Usia Dini juga dipandang penting. Seperti termaktub dalam Pembukaan Undang-Undang Dasar 1945, “... kemudian daripada itu, untuk membentuk suatu persatuan Negara Indonesia yang berkedaulatan rakyat, mencerdaskan kehidupan bangsa, dan ikut melaksanakan ketertiban dunia yang berdasarkan kemerdekaan, perdamaian abadi, dan keadilan sosial,...". Hal ini disebutkan juga dalam Amandemen UUD 1945 pasal $28 \mathrm{C}$ ayat 2, "Membuka peluang anak-anak kurang mampu untuk dapat memperoleh pendidikan yang layak seperti anak-anak lain karena pendidikan yang layak adalah hak azasi setiap manusia." Secara terperinci, hak anak untuk mendapatkan pendidikan yang layak juga disebutkan dalam Undang-undang Perlindungan Anak, RI Nomor 23 Tahun 2002 tertulis bahwa: Setiap anak berhak untuk dapat hidup, tumbuh, berkembang, dan berpartisipasi secara wajar sesuai dengan harkat dan martabat kemanusiaan, serta mendapat perlindungan dari kekerasan dan diskriminasi (pasal 4); Setiap 
anak berhak memperoleh pendidikan dan pengajaran dalam rangka pengembangan pribadinya dan tingkat kecerdasannya sesuai dengan minat dan bakatnya (pasal 9 ayat 1) dan Selain hak anak sebagaimana dimaksud dalam ayat (1), khususnya bagi anak yang menyandang cacat juga berhak memperoleh pendidikan luar biasa, sedangkan anak yang memiliki keunggulan juga mendapatkan pendidikan khusus (pasal 9 ayat 2). (Republik Indonesia, 2002:5).

Lebih lanjut, Kemdikbud (2016) memaparkan pentingnya Pendidikan Anak Usia Dini yang berkualitas, yaitu:

1. PAUD sebagai titik sentral strategi pembangunan sumber daya manusia dan sangat fundamental.

2. PAUD memegang peranan penting dan menentukan bagi sejarah perkembangan anak selanjutnya, sebab merupakan fondasi dasar bagi kepribadian anak.

3. Anak yang mendapatkan pembinaan sejak dini akan dapat meningkatkan kesehatan dan kesejahteraan fisik maupun mental yang akan berdampak pada peningkatan prestasi belajar, etos kerja, produktivitas, pada akhirnya anak akan mampu lebih mandiri dan mengoptimalkan potensi yang dimilikinya.

4. Merupakan Masa Golden Age (Usia Keemasan). Dari perkembangan otak manusia, maka tahap perkembangan otak pada anak usia dini menempati posisi yang paling vital yakni mencapai $80 \%$ perkembangan otak.

5. Cerminan diri untuk melihat keberhasilan anak dimasa mendatang. Anak yang mendapatkan layanan baik semenjak usia 0-6 tahun memiliki harapan lebih besar untuk meraih keberhasilan di masa mendatang. Sebaliknya anak yang tidak mendapatkan pelayanan pendidikan yang memadai membutuhkan perjuangan yang cukup berat untuk mengembangkan hidup selanjutnya.

Demi mempersiapkan generasi yang mampu bersaing pada revolusi industry 4.0, bahasa asing khususnya Bahasa Inggris perlu diajarkan di sekolah. Bahasa Inggris adalah bahasa internasional yang paling banyak digunakan di dunia sehingga untuk dapat berkomunikasi dengan dunia luar, kemampuan berbahasa Inggris menjadi hal yang wajib dimiliki. Bahasa Inggris merupakan bahasa pengetahuan, bahasa komputer dan internet, bahasa diplomasi sehingga penguasaaan Bahasa Inggris dapat membuka peluang untuk bersekolah di luar negeri, bekerja di perusahaan asing dan lain sebagainya.

Begitu pentingnya menguasai Bahasa Inggris sehingga anak-anak yang bersekolah di PAUD telah diperkenalkan kepada Bahasa Inggris sedini mungkin. Usia golden age yaitu 1-6 tahun adalah usia yang sangat baik untuk belajar bahasa. Anak dapat menerima bahasa apapun dengan mudah dan cepat pada usia ini. Di samping itu, Belajar bahasa asing dapat pula meningkatkan keahlian berpikir kritis, kreatifitas otak anak. Anak yang belajar bahasa asing lebih unggul pada ujian mata pelajaran lain seperti Matematika dan kemampuan verbal. Hal ini menandai bahwa belajar bahasa adalah aktifitas kognitif yang tidak hanya mengaktifkan kemampuan linguistic. Otak, seperti halnya otot, berfungsi lebih baik ketika dilatih. Belajar bahasa meliputi aturan-aturan mengingat pola dan kosa kata dapat membantu menguatkan otak.

Belajar bahasa asing sangat baik jika dimulai sedini mungkin karena anak kecil sangat pandai meniru bunyi-bunyi yang baru dan beradaptasi dengan cara pengucapan bahasa. Otak mereka masih terbuka untuk mempelajari bunyi-bunyi dan pola bahasa baru. Pada usia ini, anak memiliki waktu untuk belajar sambil bermain dan tidak malu mencoba menggunakan bahasa yang baru didengarnya.

Pengajaran bahasa Inggris pada sekolah PAUD selayaknya mendapat perhatian segala pihak terutama menyangkut tersedianya pengajar Bahasa Inggris yang berkompeten. Pengajar PAUD pada umumnya bukanlah lulusan Program Studi Pendidikan Bahasa Inggris 
yang benar-benar menguasai cara mengajar Bahasa Inggris. Mereka tidak dibekali strategi dan teknik mengajar Bahasa Inggris dan mereka harus belajar sendiri untuk kemudian mengajarkannya kepada anak.

Dari hasil survey dan wawancara dengan pengelola PAUD Al- Hikmah, yang berlokasi di Kel. Mayang Mangurai, Kota Jambi, yang akan menjadi mitra pada kegiatan pengabdian ini, tim PPM menemukan fakta bahwa PAUD Al- Hikmah bertujuan untuk membentuk PAUD yang punyai daya saing dengan meningkat kualitas pendidikan yang ada serta menargetkan anak didik untuk bisa memperoleh kemampuan bahasa Inggris sejak dini disamping bahasa Indonesia yang jelas-jelas menjadi bahasa pengantar sehari hari mereka. Namun dikarenakan keterbatasan dana, para pengajar belum mendapatkan pembekalan atau pelatihan mengajar bahasa khususnya Bahasa Inggris. Untuk itu diperlukan upaya dalam meningkatkan kualitas guru PAUD dalam mengajarkan Bahasa Inggris.

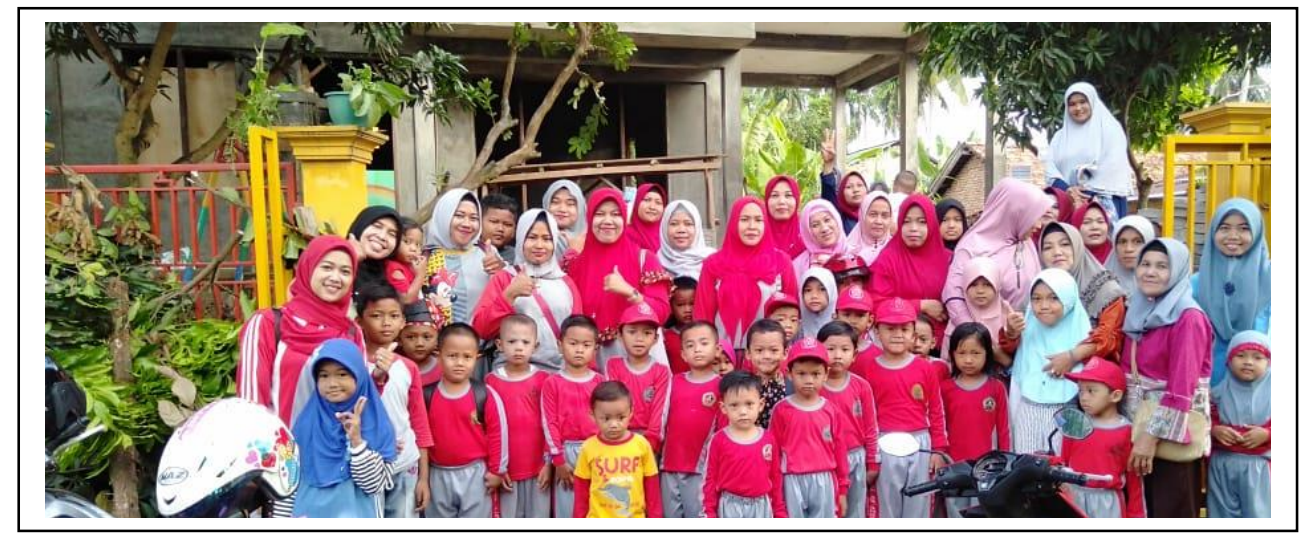

\section{Permasalahan Mitra}

Dari hasil wawancara dengan pengelola PAUD Al- Hikmah didapatkan informasi bahwa persoalan prioritas mitra adalah kurangnya kemampuan dan keterampilan guru PAUD dalam mengajarkan Bahasa Inggris. Hal ini disebabkan oleh kurangnya pelatihan dan pembekalan teknik dan metode mengajar Bahasa Inggris untuk para guru PAUD.

Untuk itu tim pengusul bersama mitra telah menentukan dan menyepakati prioritas yang akan diselesaikan selama pelaksanaan program PPM, yaitu memberikan pelatihan dan pembekalan tentang teknik dan metode mengajar Bahasa Inggris untuk para guru PAUD AlHikmah.

\section{TINJAUAN PUSTAKA}

Pembelajar untuk anak-anak usia dini memiliki karakteristik yang berbeda dengan pembelajar dewasa. Menurut Harmer (2001) setidaknya ada tujuh sifat belajar anak-anak yangberbeda dengan orang tua. Di antara sifat itu adalah anak akan merespon terhadap makna walaupun mereka tidak mengerti semua kata-kata secara keseluruhan. Anak- anak juga cenderung belajar dari lingkungan sekitar. Mereka belajar tidak hanya dari apa yang di dengar dan dilihat tetapi juga dari apa yang mereka lakukan. Selaian itu anak-anak juga memiliki waktu untuk konsentrasi yang terbatas. Dengan adanya perbedaan sifat tersebut, perlakuan terhadap anak-anak juga harus berbeda dengan perlakuan terhadap pembelajar dewasa. Lebih jauh, menurut Claire (1988), anak-anak belajar dengan menggunakan seluruh panca indra mereka. Total physical response adalah cara yang pada beberapa hal baik untuk memfasilitasi anak-anak belajar. Agar tujuan pembelajar bisa tercapai secara baik, seorang 
guru di tuntut untuk bisa menciptakan suasana dan kondisi belajar yang sesuai dengan sifat anak-anak seperti tersebut di atas. Selain itu ia juga diharapkan bisa menggunakan teknik pembelajaran yang menarik sesuai dengan dunia anak-anak tersebut. Brewster menekankan pentingnya pemilihan resources atau sumber belajar bagi anak-anak. Diantara sumber belajar yang menguntungkan bagi anak anak adalah lagu, cerita dan permainan juga crafting (keterampilan).

\section{Lagu}

Sebelum menentukan pilihan lagu yang akan digunakan, guru perlu melakukan beberapa pertimbangan: Pertama, lagu sudah dikenal atau disukai siswa. Ini dapat diketahui dengan cara, misalnya guru bertanya langsung pada siswa tentang lagu-lagu yang disukai atau kelompok musik mana yang mereka kenal, dan seterusnya. Kedua, lagu harus berisi materi yang akan diajarkan, baik keterampilan bahasa maupun unsur bahasanya. Ketiga, lagu harus memiliki sifat dan karakter yang mengandung pencapaian tujuan pembelajaran. Keempat, lagu harus memiliki tingkat kesulitan yang sesuai dengan kemampuan siswa. Kelima, lagu harus berisi pesan atau nilai yang sesuai dengan tingkat usia dan kematangan siswa. Setelah menentukan lagu yang akan digunakan, guru bisa menentukan keterampilan berbahasa dan unsur bahasa apa yang akan dikembangkan. Beberapa contoh jenis kegiatan atau pendekatan yang dapat digunakan adalah drills. Drill di sini berupa oral drill. kegiatan pembelajaran berikut dapat dilakukan melalui listening practice atau repetition drill.

\section{Cerita}

Menurut Wright (1995:3), cerita yang di dalamnya termuat sejumlah banyak kata, menyajikan pengalaman bahasa yang kaya. Selain itu cerita juga mampu memotivasi, kaya unsur pengalaman bahasa dan tidak mahal.

\section{Permainan}

Toth (1995 dalam Mei and Yu-Jung, 2000) mendefinisikan permainan sebagai aktivitas yang memiliki aturan, tujuan dan di dalamnya terkandung unsur rasa senang. Lebih jauh Toth membagi permainan ke dalam competitive game dan cooperative game

\section{Crafting}

Crafting melatih siswa mengembangkan otak juga otot motoriknya. Menurut Ellis dan Brewter, Communicatiave approach mengacu pada activity-based dan seringnya melipatkan penggunaan 3 jenis aktivitas berikut ini: pertama adalah problem-solving activities misalnya identifying, matching, sequencing, prioritizing a classifying; kedua adalah interactive activities, seperti making survey, or carrying out interview dan ketiga creative activities, such as making mask, birthday cards, dan sebagainya.

\section{METODE PELAKSANAAN}

Pengabdian ini dilakukan dengan cara memperkenalkan materi bahasa Inggris kepada guruguru PAUD Al- Hikmah khususnya yang mengajar di tingkat TK atau Taman KanakKanak. Materi bahasa Inggris ini disesuaikan dengan kebutuhan peserta didik anak PAUD dengan mempertimbangkan usia dan perkembangan kognitif, afektif serta psikomotorik mereka.

Adapun tema yang diberikan kepada guru PAUD ditransferkan ke peserta didik diantaranya adalah:

1. Introduction (Perkenalan) 
2. Body Parts (Anggota Tubuh)

3. My family (keluargaku)

4. Shapes and colors (Bentuk dan Warna)

5. Food dan Drinks (makanan dan Minuman)

6. Pet and Farm Animals (binatang peliharaan dan ternak)

7. Fruits (Buah- buahan)

8. Vegetable (Sayur-sayuran)

Salah satu sumber bacaan yang dipakai yang berisikan tema di atas adalah Buku Bahasa Inggris untuk Taman Kanak-kanak yang ditulis oleh Hidayatul Maulidiyah (2014), Malang. Buku ini diperkenalkan sebagai salah satu rujukan yang bisa dipakai oleh guru-guru yang akan mengajar bahasa Inggris di PAUD tempat mereka mengajar.

Kegiatan PPM ini dilakukan secara daring dengan memanfaatkan aplikasi Zoom mengingat kondisi lingkungan dan masyarakat yang belum kondusif akibat COVID-19. Kegiatan Pengabdian Kepada masyarakat ini telah dilaksanakan pada hari Selasa, tanggal 29 Juli 2020. Dari 12 guru yang deirencanakan ikut terlibat dalam online meeting ini, yang bisa hadir 10 orang karena yang lain terkendala dengan perangkat yang tidak bisa menginstal aplikasi Zoo

\section{HASIL}

Kegiatan Pengabdian Kepada masyarakat ini telah dilaksanakan pada hari Selasa, tanggal 29 Juli 2020. Mengingat dan menimbang situasi belum kondusif dikarenakan masalah Covid-19, maka kegiatan ini dilakukan secara daring atau online dengan memanfaatkan aplikasi Zoom. Dari 12 guru yang deirencanakan ikut terlibat dalam online meeting ini, yang bisa hadir 9 orang karena yang lain terkendala dengan perangkat yang tidak bisa menginstal aplikasi Zoom. Kegiatan berjalan dengan lancar walaupun pada awalnya mengalami masalah yang kemungkinan disebabkan oleh perangkat komputer atau jaringan internet yang kurang stabil. Ini bisa menjadi pengalaman berharga baik kami sebagai pelaksana kegiatan PPM dan guru atau pihak sekolah mitra agar kedepannya bisa lebih baik lagi jika akan melaksanakan kegiatan serupa yang memanfaatkan online meeting via Zoom seperti ini.

Jadi secara tidak langsung disamping guru mendapatkan pengetahuan dari kami sebagai nara sumber dalam meningkatkan pengetahuan mereka tentang bahasa Inggris yang bisa mereka terapkan di sekolah, mereka juga mendapatkan pengalaman dalam melakukan pertemuan secara online dengan menggunakan aplikasi kekinian yaitu Zoom. Pengalaman ini yang mungkin tidak didapatkan ketika pertemuan dilakukan secara offline. dan ini juga menunjukkan bahwa guru-guru paud juga tidak gaptek atau gagap teknologi.

Adapun kendala yang dihadapi dalam pengabdian ini adalah

1. masalah kondisi lingkungan yang belum kondusif, sehingga kegiatan yang di rencana awal akan dilakukan secara off line, terpaksa diganti dengan sistem online.

2. Selanjutnya dengan sistem online melalui penggunaan aplikasi Zoom, muncul lagi kendala diantaranya, ada peserta yang sudah siap untuk ikut acara via zoom dan suadah stand by di sekolah, ternyata perangkat HP nya tidak memungkinkan untuk mengoperasikan zoom dikarenakan memori yang tidak cukup.

3. Kelancaran Zoom terganggu karena perangkat dari host yang kurang support. ternyata untuk menjadi host zoom yang merupakan media pertemuan online yang kekinian, juga memerlukan laptop yang juga kekinian alias spesifikasinya harus lebih baik sesuai dengan tuntutan zaman. Sebagai solusinya akhirnya dibantu 
dengan HP host, android windows 10, yang sudah up to date atau spesifikasi yang lebih baik, dari laptop untuk bisa menjalankan zoom meeting.

Dari masalah yang timbul di atas, akhirnya membuat kami banyak belajar untuk lebih baik ke depan ketika akan melakukan kegiatan serupa yang mengharuskan penggunaan perangkat eloktronik yang lebih layak sesuai dengan tuntutan aplikasi yang di pakai. namun demikian kita tidak boleh melupakan faktor X. apa itu faktor X? faktor X di sini adalah faktor yang tidak terduga yang menyebabkan kegiatan yang telah kita persiapkan secara matang, tidak bisa terlaksana sesuai dengan harapan 100 persen. Contoh masalah yang tidak terduga misalnya, perangkat laptop tiba-tiba bermasalah, sedangkan peserta yang akan ikut zoom meeting sudah siap. Ini membuat situasi agak kacau dan tidak mengenakkan. Agar hal tersebut tidak terjadi, bisa disiapkan perangkat laptop cadangan untuk antisipasi kalau laptop pertama bermasalah. Selanjutnya bisa juga dicoba alternatif online meeting yang lainnya seperti GOOGLE MEET. Antara keduanya memiliki kelebihan dan kekurangan, tapi untuk yang pertemuan yang hanya sekedar memabagikan infomasi dan tidak dibatasi waktunya, ada baiknya memakai GOOGle MEET. Untuk lebih jelas,bisa dicek sendiri di google.

Terlepas dari semua kendala yang muncul, yang jelas kegiatan ini sudah dilaksanakan dan mendapat respon positif dari pihak mitra baik dari pemilik yayasan dan guru-guru PAUD itu sendiri. Harapan ke depannya mudah-mudahan dengan adanya kegiatan ini, mereka, guru-guru di sana bisa mengembangkan pengetahuan mereka dan terus mengupdate informasi terutama berkaitan dengan Bahasa Inggris karena menurut teori semakin dini anak mempelajari bahasa asing, maka semakin baik.

\section{KESIMPULAN DAN SARAN}

\section{Kesimpulan}

1. Kegiatan Pengabdian Kepada Masyarakat (PPM) dapat terlaksana berkat adanya kerjasama yang baik antara tim dan pihak mitra.

2. Sebaik apapun rencana awal kita, ada faktor $x$ yang tidak bisa kita duga muncul sehingga dapat menghambat proses pelaksanaan kegiatan. Di sinilah dituntut kejelian, daya tanggap serta kreativitas dalam menghadapi faktor $\mathrm{x}$ tersebut seperti yang telah dijelaskan di bab 5 .

\section{Saran}

1. Semoga kedepannya akan banyak lagi kegiatan dalam upaya peningkatan keilmuan pendidik khususnya yang berkaitan dengan pengajaran bahasa Inggris.

2. Sebaiknya perangkat penunjang proses kegiatan seperti laptop dipersiapkan sebaik mungkin kalau ingin melakukan kegiatan secara daring. Karena biasanya kegiatan daring seperti zoom ini menuntut kemampuan laptop yang handal apalagi kalau sebagai host atau pemilik acaranya. Artinya, usahakan laptop yang dipakai punya daya kerja yang baik dan daya akses yang cepat. Tentunya itu ada pada laptop yang processornya kekinian.

\section{DAFTAR PUSTAKA}

Brewster, J., Ellis, G., \& Girard, D..2002. The Primary English Teacher's Guide. England: Pearson plc.

Claire Hewlett, Hellen Ward, Judith Roden \& Julie Foreman. 1988. Teaching Science in the Primary Classroom: A Practical Guide (Paperback). Paul Chapman publishing A SAGE Publications. 
Harmer, Jeremy. 2001. The Practice of English Language Teaching with DVD (4th Edition) London: Longman Handbooks for Language Teachers.

Kemdikbud. 2016.. Memahami Pendidikan Anak Usia Dini. Retrieved from http://paud.kemdikbud.go.id/2016/03/30/memahami-pendidikan-anak-usia-dini/

Maulidayah, Hidayatul. 2014. Bahasa Inggris untuk Taman Kanak- kanak. Malang:-

Mei , Yin Yong \& Yu-jing, J. 2000. From using games in an EFL class for children. Daejin University ELT Research Paper. Fall, 2000.

http://english.daejin.ac.kr/ rtyson/fall2000/elt/games.html retrieved 20 February 2010

Republik Indonesia. 2002. Undang-Undang No. 23 Tahun 2002 tentang Perlindungan Anak. Lembaran Negara RI Tahun 2002, No. 109. Sekretariat Kabinet RI. Jakarta.

Richard, J.C., Schmidt, R., Kendricks,H., \& Kim, Y. 2002. Longman Dictionary of Language Teaching and Applied lingistics.UK: Pearson Education.

Wright, A. 1995. Story Telling with Children. Oxford: OUP.

Wright, A., Betteridge,D. \& Buckby, M. 1984. From games for language learning,Cambridge: Cambridge University Press.

www.unja.ac.id. Diakses 24 Februari 2020 